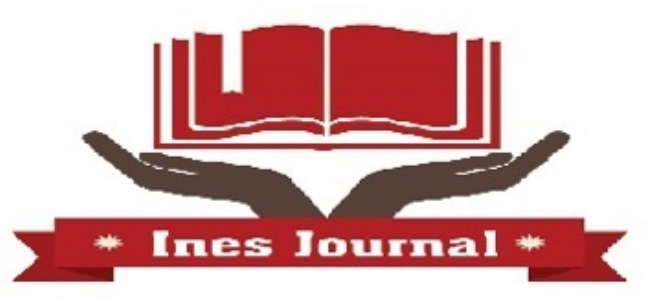

Yıl: 2, Sayı: 5, Aralık 2015, s. 477-489

\section{INESJOURNAL}

ULUSLARARASI EĞİTIMM BİLİMLERİ DERGİSİ THE JOURNAL OF INTERNATIONAL EDUCATION SCIENCE

\title{
Metin ÖZKAN ${ }^{1}$ \\ PISA 2012 TÜRKIYYE VERILERİNE GÖRE OKUL DEĞISSKENLERİNİN ÖĞRENCİ BAŞARISINI YORDAMA GÜCÜ
}

\begin{abstract}
Özet
Bu araştırmada, okul ile ilgili değişkenler olan sınıf büyüklüğü, okulda yapılan ekstra etkinlikler, eğitimsel ve fiziksel kaynakların kalitesi, öğrenci ve öğretmenle ilişkili faktörlerin etkilediği okul iklimi, öğrenci/öğretmen oranı ve okul büyüklüğü değiş̧kenlerinin öğrenci başarısını ne derece yordadığının belirlenmesi amaçlanmıştır. Betimsel nitelikteki araştırma, ilişkisel tarama modelinde desenlenmiştir.Araştırmanın örneklemi, tabakalı örnekleme yöntemiyle Türkiye'deki 15 yaş grubu öğrencilerin öğrenim gördüğü 170 farklı okuldan seçilmiş toplam 4511 öğrenciden oluşmaktadır. Araştırma kapsamında belirlenen okul değişkenlerinin öğrenci başarısını ne derece yordadığını belirleyebilmek amacıyla çoklu regresyon analizinden yararlanılmıştır. Analiz sonuçları incelendiğinde yordayıcı değişkenlerin, okul başarı puanlarındaki toplam varyansın \% 29'unu açıklayabildikleri anlaşılmaktadır. Araştırma kapsamında ele alınan tüm okul değiş̧kenlerinin öğrenci başarısı üzerinde anlamlı bir yordayıc1 olduğu görülmektedir. Öğrencilerin başarılarını yordamada en yüksek etkiye sahip değişken, öğrenciyle ilişkili faktörlerin etkilediği okul iklimi değişkenidir. $\mathrm{Bu}$ değişskenin ardından yordayıcı değiş̧kenlerin öğrenci başarısı üzerindeki göreli önem sırasının; eğitimsel kaynakların kalitesi, okulda öğrencilere sunulan ekstra etkinlikler, öğretmenle ilişkili faktörlerin etkilediği okul iklimi, fiziksel kaynakların kalitesi, öğrenci/öğretmen oranı, sınıf büyüklüğü ve okul büyüklüğü olduğu söylenebilir.
\end{abstract}

Anahtar Kelimeler: Öğrenci başarısı, okul iklimi, öğrenci/öğretmen oranı, PISA

\section{THE PREDICTIVE POWER OF SCHOOL VARIABLES FOR STUDENT ACHIEVEMENT ACCORDING TO PISA 2012}

\begin{abstract}
In this study, the variables that are associated with the class and school size, extracurricular activities at school, quality of physical infrastructure, quality of schools' educational resources, students and school climate to influence factors associated with teaching and student / teacher ratio is aimed to determine to what extent predicted student achievement. A relational survey method is used in this study. Sample of study is consist of 4511
\end{abstract}

1Yrd. Doç. Dr., Gaziantep Üniversitesi, Gaziantep Eğitim Fakültesi, Eğitim Bilimleri Bölümü, ozkan.metin@gmail.com 


\section{Metin ÖZKAN}

students selected from 170 different schools by stratified sampling method. Multiple regression analysis was used for to determine schools variables that influence student achievement. According to the analysis, predictor variables could explain $29 \%$ of the total variance in school achievement scores. It's understood all school variables in under researched are significant predictor on student achievement. The index of student-related factors affecting school climate having the highest impact predictors of student success. Than, on student achievement relative importance of predictor variables as: The index of quality of school educational resources, the index of creative extracurricular activities at school, the index on teacher-related factors affecting school climate, the index of quality of physicals' infrastructure, student/teacher ratio, classroom size and school size.

Key Words: Student achievement, school climate, student-teacher ratio, PISA

\section{GİRIŞ}

Bireyde istendik davranışlar kazandırma süreci olarak tanımlanan eğitimin ve örgün yapılanmasını sağlayan eğitim sistemlerinin nihai, sonul, öncelikli amacı öğrenci öğrenmeleridir. Dolayısıyla olduğu günden bugüne okulların varlık nedeni, öğrencilerin planlı ve programlı bir şekilde, doğal yaşam koşulları içerisinde kendi kendilerine öğrenebileceğinden, edinebileceğinden daha fazlasını bireylere kazandırmaktır. Toplumsal yaşamın her geçen gün karmaşıklaşması, okulların bu rolünün artarak ve pekişerek devam etmesini sağlamaktadır. Bireyin değişen toplumsal yaşama uyum sağlayabilmesinde örgütlü bir sistem olarak okulun önemi, tartışılmaz bir biçimde giderek artmaktadır (Altınkurt, 2008). Bu durumun bir sonucu olarak okullar, toplumlar için ontolojik ve epistemolojik açıdan bir kabulden öte zorunluluk olarak kurumsal varlığını devam ettirmektedir.

Emek yoğun işgücünden, bilgi yoğun işgücüne geçişte toplumların en önemli kaynağ 1 konumunda yer alan insanın, okulda, istendik davranışlarla donatılması çağın gereği olarak kendini göstermektedir. Bu nedenle okulların istendik davranışları kazandırmada yeterlikleri tüm toplumu ilgilendiren bir konudur. Eğitim sürecinin başından itibaren tüm amaç belirleme çalışmaları, bu amaçlara ulaştıracak araçları saptama ve kullanma yöntemleri ile amaçlara ulaşma düzeylerini belirleme çabalarının hedefi öğrencilerin başarı düzeylerini yükseltmektir (Kurul Tural, 2002). Genel anlamda düşünüldüğünde, toplumlar için okulların başarılı olmasının bir gereklilik olduğu söylenebilir.

Daha dar kapsamlı düşünüldüğünde eğitim sisteminin en önemli paydaşlarından biri olan öğrenciler, dolayısıyla veliler, mensubu oldukları okulların hedeflenen davranışları kazandırmada etkili olmasını beklemektedirler. Çocuk ve gençlerin yetiştirilmesinde en çok sorumluluğu olan iki kurum vardır: Okul ve aile (Özdemir, 2002). Dolayısıyla aileler kendisi ile birlikte ortak sorumluluğu paylaştığı okulların eğitimsel hedefleri gerçekleştirme konusunda üzerine düşeni ve hatta bu konudaki kendi eksikliklerini de kapatması yönünde istemde bulunmaktadır. Kurul Tural (2002)'da öğrenci başarısını açıklayan fonksiyonun önemli bir girdisi olarak okul kaynaklarına işaret etmektedir. Ailenin toplumsal yaşamdaki büyük önemine rağmen, günümüz şartları dikkate alındığında eğitimsel açıdan kendisinden beklenen görevi yeterince yerine getirdiği söylenememekte, bu bakımdan çocuk ve gençlerin yetiştirilmesi geniş ölçüde okulların sorumluluğu altında gerçekleşmektedir (Özdemir, 2002). 
Veliler, öğrencilerini göndermek için bir okul tercihi yapmaları gerektiğinde, ya da gönderme mecburiyetinde kaldığında, öncelikli olarak bu okulun çocuğu için uygun bir öğrenme ortamı sağlayıp sağlamayacağını sorgulamaktadırlar. Bu durumun ana nedeni olarak, eğitim amaç ve hedeflerinin gerçekleştirilmesi konusunda uçtaki tek kurum olarak tasarlanan okulun, öğrenme olgusunun gerçekleştiği biçimsel ortamların en büyüğü ve en yaygın olması gösterilebilir (Açıkalın, 2014).

Akademik anlamda düşünüldüğ̈̈nde öğrencilerin okuma becerilerindeki yeterliliği, problem çözme becerilerindeki gelişimi, kritik düşünme süreçlerini okuldaki eğitim öğretim etkinlikleri ile kazanmış olması beklenir (Berberoğlu ve Kalender, 2005). Sonuç olarak okullar toplumun, ailelerin ve öğrencilerin beklentilerini ve çağın gerekliliklerini kazandırması sorumluluğunu üzerinde taşıyan yapılar olarak ifade edilebilir. Okulun bu sorumlulukları yerine getirip getiremediği çeşitli değişkenlerle bütüncül olarak değerlendirilmesi gerekmekle birlikte, bu değerlendirme somut, yaygın ve kestirme bir yoldan öğrenci akademik başarısı üzerinden yapılmaktadır.

Küreselleşme, ulusal sınırların esnemesi, öğrenci hareketliliği, dünya vatandaşlığı, hareketli işgücü gibi kavramların ortaya çıkması ve gelişmesi nedenleriyle ülkeler ulusal düzeyde akademik başarıyı belirleme ve değerlendirme çalışmalarının yanı sıra başarılarını uluslararası düzeyde görmek ve karşılaştırmak amacıyla çeşitli uluslararası ölçme ve değerlendirme çalışmalarına da katılmaktadırlar. Bu çalışmalardan biri ülke olarak kurucu üyesi olduğumuz İktisadi İşbirliği ve Kalkınma Teşkilatı (OECD)'nın uygulamaya koyduğu Uluslararası Öğrenci Başarılarını Değerlendirme Projesi (PISA)'dır. PISA araştırması OECD ülkelerindeki 15 yaş grubu öğrencilerin zorunlu eğitim sonunda, aktif bir üyesi olacakları bilgi toplumunda karşılaşabilecekleri durumlar karşısında ne ölçüde hazırlıklı yetiştirildiklerini belirlemek amaciyla geliştirilmiştir (MEB, 2015).

PISA'da öğrencilere başarılarını ölçmek amacıyla uygulanan bilişsel testin yanı sıra öğrencinin çok yönlü değerlendirilmesine katkı sağlayacak, eğitimin paydaşlarını işe koşan öğrenci, veli ve okul anketleri de uygulanmaktadır. Öğrenci anketinde öğrenciye kendisi, ailesi ve evi, matematik öğrenimi, bilişim teknolojilerini kullanımı ve erişimi ile ilgili sorular yöneltilirken; okul anketinde okul müdürü veya yetkili birine okul yapısı ve organizasyonu, kaynakları, iklimi, eğitim politikaları ve uygulamaları, öğrenci ve öğretmenlerle ilgili sorular yöneltilmektedir. Dolayısıyla okul anketinden elde dilen bilgiler ulusal ve uluslararası düzeyde okul kaynaklarının kullanılabilirliğinin öğrenci başarısı üzerindeki etkilerini ortaya koymada ve farklı okul grupları arasındaki benzerlik ve farklılıkların incelenmesine katkı sağlayabilmektedir. Bu yönüyle PISA projesi bir taraftan öğrenci akademik başarısını uluslararası ölçekte ortaya koyarken diğer taraftan akademik başarının okul değişkenleri ile ilişkilendirilebilmesine imkan vermektedir.

Türkiye'nin 2003 yılından itibaren, geniş ölçekte ve evreni temsil edebilecek düzeyde üç yıllık periyotlarla yapılan PISA uygulamasına katılmasıyla elde edilen veriler eğitim sistemin değerlendirilmesi veya izlenmesinde farklı çalışmalara (Albayrak, 2009; Anıl, 2008, 2009; Akyüz ve Pala, 2010; Boztunç, 2010; Çifçi, 2006; Erbaş, 2005; Gürsakal, 2012; Güzel, 2006; Koğar, 2015; Özer, 2009; Özer ve Anıl, 2011; Şaşmazel, 2006; Usta, 2009; Yıldırım, 2009; Ziya, Doğan ve Kelecioğlu, 2010) konu olmuştur. Yapılan çalışmalar incelendiğinde bu çalışmaların öğrenci anketinde yer alan çeşitli değişkenlerin öğrenci başarısı üzerine etkisini araştıran çalışmalar olduğu anlaşılmaktadır. Buna karşılık, ulusal alanyazında okula ilişkin 
değişkenlerle öğrenci başarısı arasındaki bağlantıyı araştıran sınırlı sayıda çalışmaya (Berberoğlu ve Kalender, 2005; Alacacı ve Erbaş, 2010; Yalçın ve Tavşancıl, 2014) rastlanılmaktadır.

Bir öğrenme ortamı olarak okulun öğrenci akademik başarısı üzerinde önemli bir etkiye sahip olduğu düşünüldügünde, geniş ölçekli uygulanan bir testten elde edilen okulla ilgili değişkenlerin akademik başarıya etkisinin incelenmesi bir gereklilik olarak görülmektedir. Bu gereklilikten hareketle araştırmanın ana problemi olan; PISA 2012 okul anketinde yer alan olan sınıf büyüklüğü, okulda yapılan ekstra etkinlikler, eğitimsel ve fiziksel kaynakların kalitesi, öğrenci ve öğretmenle ilişkili faktörlerin etkilediği okul iklimi, öğrenci/öğretmen oranı ve okul büyüklüğü değişkenlerinin öğrenci başarısını ne derece yordamaktadır? sorusuna yanıt aranmıştır.

\section{YÖNTEM}

\section{Araştırmanın Modeli}

Okulla ilgili değişkenlerin öğrencilerin PISA 2012 başarı puanlarını ne derece yordadığının belirlenmesinin amaçlandığı betimsel nitelikteki bu araştırmada ilişkisel tarama modeli kullanılmıştır. Araştırmanın modeline ilişkin süreç şeması Şekil 1'de gösterilmektedir.

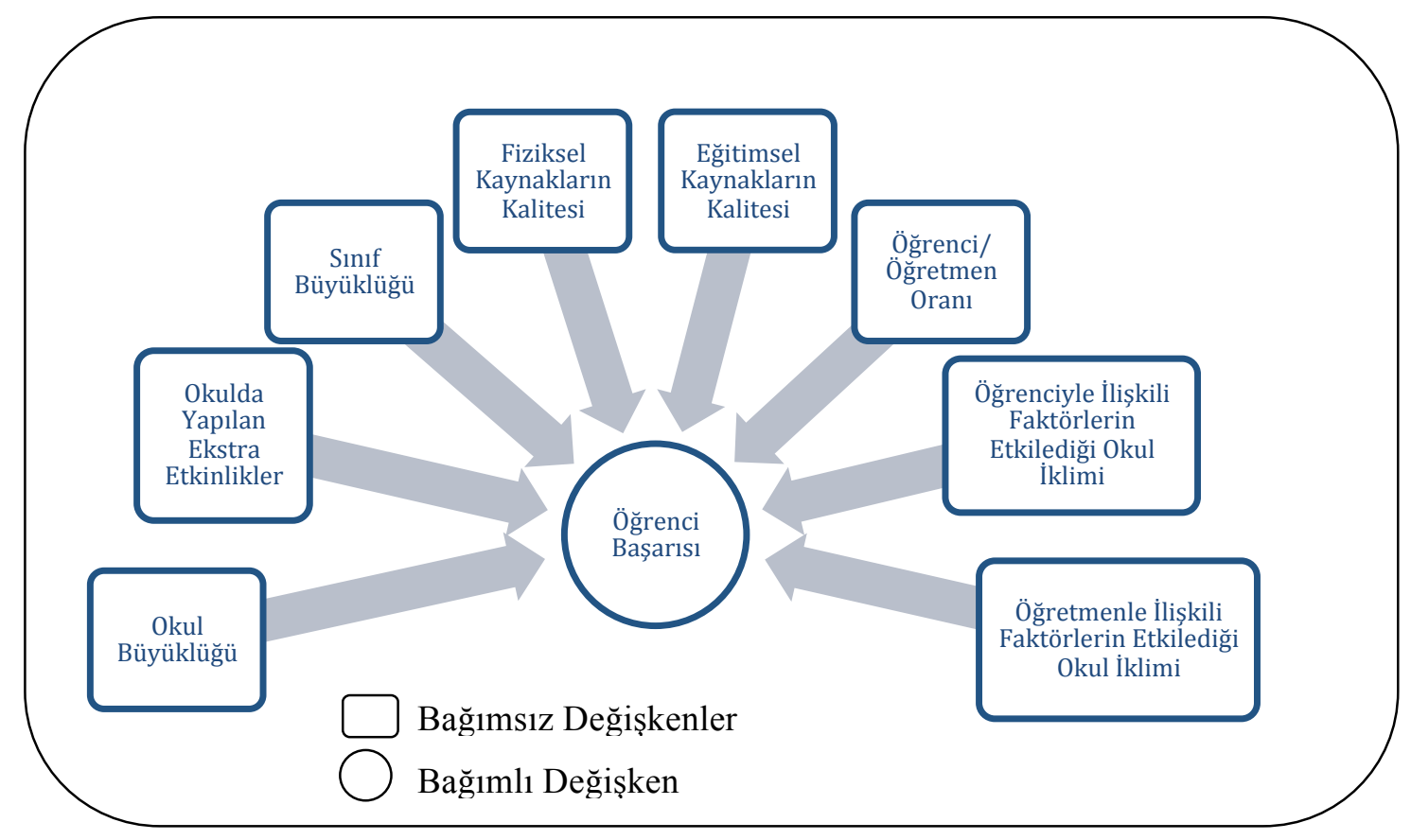

\section{Evren ve Örneklem}

Araştırmada PISA 2012 uygulamasının verileri kullanıldığı için bu bölümde, PISA uygulamasının evren ve örneklemine ilişkin kısa bilgilere yer verilmiştir. PISA genel olarak 15 yaş grubu öğrencilerini hedeflemektedir. 2012 uygulamasının yapıldığ 1 Nisan ayında herhangi bir eğitim kurumuna kayıtlı 1996 doğumlu tüm öğrenciler çalışma evreni olarak belirlenmiştir. $\mathrm{Bu}$ tarihin tam karşıllğı 16 yıl 2 ay ile 15 yıl 3 ayını tamamlayan öğrencilere karşılık gelmektedir (OECD, 2013b: 66). Evrenden örneklem seçiminde ikili bir yaklaşım dikkate 
alınmaktadır. Öncelikle evreni temsil edecek şekilde okullar seçilmekte, ardından bu okullardan öğrenciler, genellikle 170 okul ve her okuldan 35 öğrenci olmak üzere, belirlenmektedir. Türkiye'de verilen evren içerisinden bölge, program türü, okul türü, cinsiyet, kentsel-kırsal gibi 38 farklı yapı dikkate alınarak tabakalı örnekleme yöntemi ile 2012 yılında 170 okuldan 4848 öğrenci örneklemi oluşturmuştur. Araştırma kapsamında 337 öğrenciye ait veride incelenen değişkenler bakımından eksiklikler tespit edilmiş, böylece bu araştırma için belirlenen örneklemde 4511 öğrenci yer almıştır.

\section{Verilerin Elde Edilmesi}

Araştırmanın verileri OECD'nin PISA 2012 veri tabanından elde edilmiştir. Araştırmanın amacı kapsamında çalışmaya dahil edilen bağımsız değişkenler PISA 2012 kapsamında ilgili okul müdürü ya da onun yerine bakan bir yetkili tarafından doldurulan okul anketinden; bağımlı değişken ise öğrenci anketinden elde edilmiştir. Okul anketinden elde edilen okulda yapılan ekstra etkinlikler, eğitimsel ve fiziksel kaynakların kalitesi, öğrenci ve öğretmenle ilişkili faktörlerin etkilediği okul iklimi değişkenlerinde anket verilerine göre tanımlanmış indekslerden yararlanılmıştır. Okul ve sınıf büyüklüğü ile öğrenci/öğretmen oranı değişkenleri ise sürekli veri olarak elde edilmiştir. Çalışma kapsamında belirlenen indekslerin OECD (2013a: 204-207) tarafından PISA 2012 uygulamasının okul başarısı üzerine hazırlanan raporu (PISA 2012 Results: What Makes Schools Successful? Resources, Policies and Practices (Volume IV)) incelenerek hangi anket maddelerinden üretildiği aşağıda detaylı olarak sunulmuştur.

Eğitimsel Kaynakların Kalitesi (The index of quality of school educational resources): $\mathrm{Bu}$ indekse ilişkin puan okul yöneticisine yöneltilen "Verilen durumlar okulunuzdaki öğretim faaliyetlerini ne derece aksatmaktadır?" sorusunun altında yer alan; i) Fen laboratuarlarının donanımının yetersizliği ya da eksikliği; ii) Öğretim materyallerinin yetersizliği ya da eksikliği; iii) İnternet bağlantısının olmaması; iv) Öğretim amaçlı kullanılan bilgisayarın yetersizliği ya da eksikliği; v) Öğretim amaçlı bilgisayar yazılımının yetersizliği ya da eksikliği; vi) Kütüphane materyallerinin yetersizliği ya da eksikliği anket maddeleri kullanılarak elde edilmiştir.

Fiziksel Kaynakların Kalitesi (The index of quality of physicals' infrastructure): Bu indekse ilişkin puan okul yöneticisine yöneltilen "Verilen durumlar okulunuzdaki öğretim faaliyetlerini ne derece aksatmaktadır?" sorusunun altında yer alani) Okul binalarının ve okul bahçesinin yetersizliği ya da eksikliği; ii) Isıtma/soğutma ve 1şılandırma sistemlerinin yetersizliği ya da eksikliği; iii) Öğretim alanlarının (ör. Sınıflar) yetersizliği ya da eksikliği anket maddeleri kullanılarak elde edilmiştir.

Öğrenciyle İlişkili Faktörlerin Etkilediği Okul İklimi (The index of student-related factors affecting school climate): Bu indekse ilişkin puan okul anketinde okul ortamı başlığı altında yer verilen "Aşağıdaki durumlar okulunuzdaki öğrencilerin öğrenimlerini ne derece aksatmaktadır?" sorusunun altında yer alan i) Öğrencilerin keyfi devamsızlıkları; ii) Öğrencilerin dersi asması; iii) Öğrencilerin okula geç kalması; iv) Öğrencilerin zorunlu okul etkinliklerine (ör. spor günleri) ya da gezilere katılmaması; v) Öğrencilerin öğretmenlere saygılı olmaması; vi) Öğrencilerin sınıf düzenini bozması; vii) Öğrencilerin alkol ya da uyuşturucu kullanması; viii) Öğrencilerin diğer öğrencileri tehdit etmesi ya da fiziksel şiddet uygulaması anket maddelerinden elde edilmiştir. 
Ögrretmenle İliskili Faktörlerin Etkilediği Okul İklimi (The index on teacher-related factors affecting school climate): $\mathrm{Bu}$ indekse ilişkin puan i) Öğrencilerin potansiyellerinin tamamını kullanmaları için teşvik edilmemesi; ii) Öğrenci - öğretmen ilişkilerinin zayıf olması; iii) Öğretmenlerin farklı yetenek seviyesindeki öğrencilere aynı sınıf içinde eğitim vermek zorunda olmaları; iv) Öğretmenlerin çeşitli etnik kökenlerden (yani dil, kültür) öğrencilere aynı sınıf içinde eğitim vermek zorunda olmaları; v) Öğretmenlerin, öğrencilerden beklentilerinin düşük olması; vi) Öğretmenlerin, her öğrencinin ihtiyaçlarını ayrı ayrı karşılayamaması; vii) Öğretmen devamsızlı̆̆1; viii) Personelin değişime direnmesi; ix) Öğretmenlerin öğrencilere çok katı davranması; x) Öğretmenlerin derse geç kalması; xi) Öğretmenlerin derslere iyi hazırlanmaması anket maddelerinden elde edilmiştir.

Okulda Öğrencilere Sunulan Extra Etkinlikler (The index of creative extracurricular activities at school): Bu indekse ilişkin puan okul anketinde, okul öğretim programı ve değerlendirilmesi başlığı altında yer verilen "2011-2012 öğretim yılında, okulunuzda 9. sınıftaki öğrenciler için aşağıdaki etkinliklerden hangisi ya da hangileri sunulmuştur?" sorusunun maddeleri olan, (i) Koro, bando ya da orkestra; ii) Okul tiyatrosu ya da okul müzikali; iii) Resim kulübü ya da sanat etkinlikleri; iv) Gönüllülük ya da hizmet etkinlikleri, ör. ağaç dikme kampanyaları; v) Satranç kulübü; vi) Spor takımı ya da sportif etkinlikler; vii) Folklor ifadelerinden elde edilmiştir.

\section{Verilerin Analizi}

Araştırma kapsamında belirlenen okul değişkenlerinin öğrenci başarını ne derece yordadığını belirleyebilmek amacıyla analiz yöntemi olarak çoklu regresyon analizinden yararlanılmıştır. Özdamar (1999) regresyon analizini, yordanan değişken/değişkenler ile yordayıcı değişken/değişkenler arasındaki bağıntıyı incelemeye yönelik bir yöntem olarak tanımlamaktadır. Bu analizin genel amacı yordanan değişken/ler ile yordayıcı değişken/ler arasındaki ilişkiyi matematiksel modelle açıklayacak bağıntılar bulmak ve yordayıcı değişken/ler yardımıyla yordanan değişken/leri kestirmektir (Alpar, 2003). İstatistiki yöntemlerin araştırmaya konu olan veri için kullanımının uygun olup olmadığına karar vermek amacıyla öncelikle ilgili yöntemin varsayımlarının sınanması gerekmektedir. $\mathrm{Bu}$ amaçla öncelikle çoklu regresyon analizinin temel varsayımları sınanmış ve bu sınamalara ilişkin bulgular sunulmuştur.Çoklu regresyon analizine ilişkin varsayımlardan, yordayıcı değişkenlerle yordanan değişken arasındaki ilişkinin doğrusal olup olmadığının testine ilişkin doğrusallık grafiği ile normallik varsayımına ilişkin grafik aşağıda gösterilmiştir. 


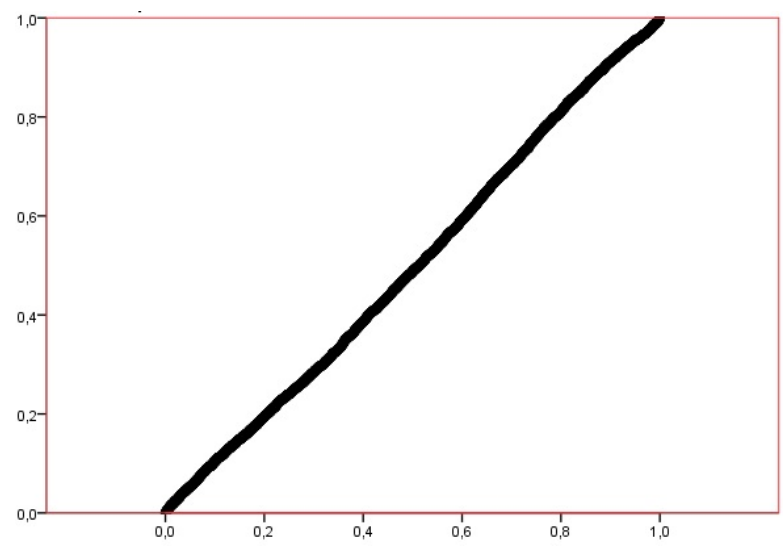

Grafik 1.Öğrenci Başarı Puanları ile Okul Değişkenleri

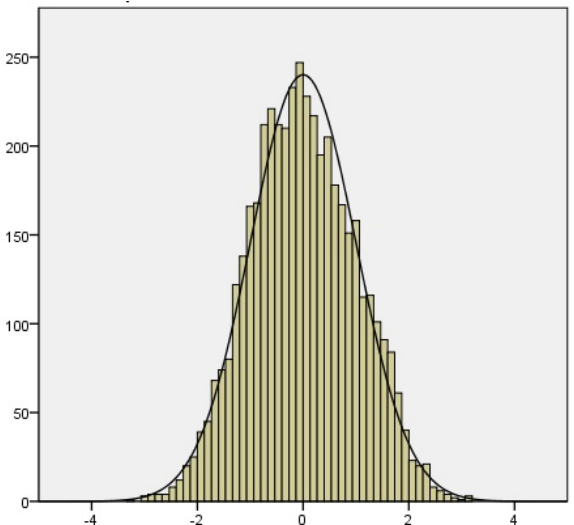

Grafik 2. Normal Dağılım Grafiği

Doğrusallık Grafiği

Grafik 1 incelendiğinde standardize edilmiş artık değerler ile standardize edilmiş yordanan değerler için oluşturulan saçılma diyagramının doğrusal bir ilişkiyi tanımladığı söylenebilir. Diğer bir anlatımla öğrenci başarı puanları ile okul değişkenleri arasında doğrusal bir ilişkinin varlığı, dolayısıyla noktaların bir eksen etrafında toplanma eğilimi içerinde olduğu ifade edilebilir. Normal dağılım grafiği incelendiğinde ise standardize edilmiş yordanan değerler için oluşturulan histogram ve normal dağılım eğrilerinin de normale yakın bir dağılım gösterdiği ileri sürülebilir (Büyüköztürk, 2006). 


\section{BULGULAR VE YORUM}

Okul değişkenlerinin öğrenci başarılarını yordamasına ilişkin çoklu regresyon analizi sonuçları Tablo 1'de gösterilmiştir.

Tablo 1. Öğrenci Başarısının Yordanmasına İlişskin Çoklu Regresyon Analizi Sonuçları

\begin{tabular}{|c|c|c|c|c|c|}
\hline Değişken & B & $\begin{array}{l}\text { Standart } \\
\text { hata }\end{array}$ & $\mathbf{B}$ & $\mathbf{T}$ & $\mathbf{p}$ \\
\hline Sabit & 510,254 & 6,019 & & 84,770 & 000 \\
\hline Sınıf Büyüklüğü &,- 604 &, 110 &,- 071 & $-5,491$ & ,000 \\
\hline $\begin{array}{l}\text { Okulda Öğrencilere Sunulan Extra } \\
\text { Etkinlikler }\end{array}$ & 17,768 & 1,191 & ,198 & 14,920 & ,000 \\
\hline Okul Büyüklüğü &,- 018 & ,003 &,- 112 & $-6,921$ & ,000 \\
\hline Fiziksel Kaynakların Kalitesi & $-7,144$ & 1,536 &,- 075 & $-4,650$ & ,000 \\
\hline Eğitimsel Kaynakların Kalitesi & 21,807 & 1,584 & 218 & 13,768 & ,000 \\
\hline Öğrenci/Öğretmen Oranı & $-1,913$ & ,193 &,- 154 & $-9,911$ & ,000 \\
\hline $\begin{array}{l}\text { Öğrenciyle İlişkili } \quad \text { Faktörlerin } \\
\text { Etkilediği Okul İklimi }\end{array}$ & 28,430 & 1,545 & ,314 & 18,405 &, 000 \\
\hline $\begin{array}{l}\text { Öğretmenle } \quad \text { İlişkili } \\
\text { Etkilediği Okul İklimi }\end{array}$ & $-7,703$ & 1,411 &,- 092 & $-5,458$ & ,000 \\
\hline
\end{tabular}

$\mathrm{R}=0.53 \mathrm{R}^{2}=0.29$ Düzeltilmiş $\mathrm{R}^{2}=0.29$

$\mathrm{P}=.0000 \mathrm{~F}_{(8,4510)}=227.300$

Çoklu regresyon analizi sonuçları incelendiğinde belirleme katsayısının 0,29 olduğu görülmektedir. $\mathrm{Bu}$ değerin 0,29 olması bu çalışma için belirlenen yordayıcı değişkenlerin, öğrenci başarı puanlarındaki toplam varyansın \% 29'unu açıkladığını göstermektedir. Tablo 1 'de regresyon katsayılarının anlamlılığına ilişkin t-testi sonuçları incelendiğinde tüm okul değişkenlerinin öğrenci başarısı üzerinde anlamlı bir yordayıcı olduğu görülmektedir. Ayrıca beta katsayılarına bakıldığında sınıf büyüklüğü, okul büyüklüğü, fiziksel kaynakların kalitesi, öğrenci/öğretmen oranı ve öğretmenle ilişkili faktörlerin etkilediği okul iklimi değişkenlerinin negatif bir etki oluşturdukları anlaşılmaktadır.

Elde ettiğimiz regresyon modelinin uygunluğunun test edilmesi için varyans analizi yapılmış ve bu analize ilişskin bulgular Tablo 2'de sunulmuştur.

Tablo 2.Regresyon Analizi için Varyans Analizi Tablosu

\begin{tabular}{|c|c|c|c|c|c|}
\hline $\begin{array}{l}\text { Varyasyon } \\
\text { (Değişim) } \\
\text { Kaynağ1 }\end{array}$ & $\begin{array}{l}\text { Serbestlik } \\
\text { Derecesi } \\
(\mathrm{sd})\end{array}$ & $\begin{array}{l}\text { Kareler Toplamı } \\
\text { (KT) }\end{array}$ & $\begin{array}{l}\text { Kareler } \\
\text { Ortalaması } \\
(\mathrm{KO})\end{array}$ & F İstatistiği & $\mathrm{p}$ \\
\hline Regresyon & 8 & 11394183,428 & 1424272,928 & 227,300 &, $000^{\mathrm{a}}$ \\
\hline Hata (Artık) & 4502 & 28209738,047 & 6266,046 & & \\
\hline
\end{tabular}




Toplam $\quad 4510 \quad 39603921,475$

Tablo 2'de kurulan modelin geçerliğine ilişkin yapılan varyans analizi sonuçları, $\mathrm{F}_{(8 ; 4502)}=$ 227,300 > 3,98 olduğu için bu sonuç denklemin önemli olduğunu göstermektedir. Bu bulgudan da hareketle araştırma kapsamında ele alınan değişkenlerin öğrenci başarısını yordamasına ilişkin regresyon denklemi aşağıdaki şekilde verilmiştir.

Öğrenci Başarısı $=510.254-0.604 *$ Sinıf Büyüklüğ̈̈ $+17.768 *$ Okulda Öğrencilere Sunulan Extra Etkinlikler - 0.018*Okul Büyüklüğ̈̈ - 7.144*Fiziksel Kaynakların Kalitesi + 21.807*Eğitimsel Kaynakların Kalitesi $-1.913 *$ Öğrenci/Öğretmen Oranı + Öğrenciyle İlişkili Faktörlerin Etkilediği Okul İklimi*28.430 - 7.703*Öğretmenle İlişkili Faktörlerin Etkilediği Okul İklimi

Regresyon denkleminde de görüldüğü gibi; öğrencilerin başarılarını yordamada en yüksek faktör öğrenciyle ilişkili faktörlerin etkilediği okul iklimi değişkenidir. Bağlantı katsayısına göre yordayıcı değişkenlerin öğrenci başarısı üzerindeki göreli önem sırasının; eğitimsel kaynakların kalitesi, okulda öğrencilere sunulan extra etkinlikler, öğretmenle ilişkili faktörlerin etkilediği okul iklimi, fiziksel kaynakların kalitesi", öğrenci/öğretmen oranı, sınıf büyüklüğü ve okul büyüklüğü olduğu söylenebilir.

\section{SONUÇ VE TARTIŞMA}

$\mathrm{Bu}$ araştırmada, okul ile ilgili değişkenlerin öğrenci başarısını ne derece yordadığının belirlenmesi amaçlanmıştır. $\mathrm{Bu}$ amacı gerçekleştirmek için yapılan çoklu regresyon analizi sonucunda yordayıcı değişkenler olan, sınıf büyüklüğü, okulda yapılan ekstra etkinlikler, eğitimsel ve fiziksel kaynakların kalitesi, öğrenci ve öğretmenle ilişkili faktörlerin etkilediği okul iklimi, öğrenci/öğretmen oranı ve okul büyüklüğ̈̈ ile yordanan değişken olan öğrenci başarısına ilişkin bir regresyon modeli oluşturulmuştur. Modele dahil edilen tüm yordayıcı değişkenlerin öğrenci başarısı üzerinde anlamlı bir etkiye sahip oldukları görülmüştür.

Araştırma sonuçlarına göre öğrenci başarısını yordamada en önemli değişkenin öğrenciyle ilişkili faktörlerin etkilediği okul iklimi değişkeni olduğu görülmektedir. Bu indeks öğrenme engelleri olarak ifade edilebilecek olan okul iklimini etkileyen öğrenci devamsızlıkları, öğrencilerin okul etkinliklerine katılmaması, alkol-uyuşturucu kullanma durumları, öğretmene saygılı olmaması ve diğer öğrencileri tehdit etmesi ya da fiziksel şiddet uygulaması gibi anket maddelerinden elde edilmiştir. Verilen durumlar doğal olarak okuldaki öğrenme ortamının kalitesini etkileyebilecek bir ortamın olmasını neden olmaktadırlar. Ortam veya iklim genel anlamda okuldaki tüm yaşamı kuşatan, olay ve olguları tanımlamaya ve anlamlandırmaya ilişkin her şeydir. Hiç bir eleman ve birimin okulda hâkim olan iklimin etkisi altında kalmaması mümkün değildir (Özdemir, 2002). Dolayısıyla öğrenme ortamını bozan öğrenci davranışları, en çok öğrencileri etkileyerek bir bütün olarak okul akademik başarısının düşük olmasında en belirleyici öğelerden biri olabilmektedir.

Etkili okul hareketinin önemli temsilcilerinden olan Lezotte (2010), etkili bir okulun öncelikle öğrenciler için fiziksel ve duygusal olarak kendilerini güvende hissedebilecekleri bir ortam sağlaması gerektiği üzerinde durmaktadır. Bu ise ancak tüm paydaşları ile okulun öğrenme 


\section{Metin ÖZKAN}

üzerine odaklanması ile mümkün olabilmektedir. Böyle bir ortamın kavga, zorbalık ve taciz gibi şiddet içerikli eylemleri barındırmasının beklenmeyeceği ifade edilebilir. Bu tür davranışlar, davranışın muhatabı olan öğrenciler dışındaki öğrenciler için de okulun yaşanabilir bir ortam olma derecesini etkileyebilmektedir. Böyle bir ortam öğrencilerin bulunmaktan imtina edebileceği bir yapıya dönüşebilmektedir. Altınkurt (2008) tarafından öğrenci devamsızlıklarının nedenlerini ve akademik başarıya olan etkisini belirlemek amacıyla yapılan çalışma sonucunda öğrencilerin başarıları ile devamsızlıkları arasında negatif bir ilişki bulunmuştur. Diğer bir anlatımla devamsızlığın öğrenci başarısı üzerinde olumsuz bir etkiye sahip olduğu söylenebilir. Bu ise formel eğitimin kazanımlarının öğrencilere aktarılmasında, bir sosyal ortam olarak informel kazanımlarda dahil olmak üzere, kayıplara neden olabilmektedir.

Öğrenci başarısını yordayan diğer değişkenler önem sırasına göre incelendiğinde, ikinci önemli yordayıcı değişkenin eğitimsel kaynakların kalitesi olduğu görülmektedir. Diğer bir anlatımla, okulların kaliteli eğitimsel kaynaklara sahip olması öğrenci ve genel olarak okul akademik başarısı üzerinde önemli bir belirleyicidir. Borman ve Dowling (2012), ünlü Coleman Raporu verilerini kullanarak oluşturdukları modelde öğrenciler arasındaki başarı farklılıklarının \%40'ının okul kaynakları ve kalitesiyle açıklanabildiğini göstermişlerdir. Ulusal alanyazında eğitimsel kaynakların kalitesi ile öğrenci ya da okul başarısı arasındaki ilişkiyi araştıran çalışmalara rastlanılamamakla birlikte bu iki değişken arasındaki ilişkinin varlığ bir olgu olarak değerlendirilebilir. $\mathrm{Bu}$ noktadan hareketle, eğitimsel kaynakların kalitesinin arttırılmasının eğitim çıktıları üzerinde olumlu etkiler oluşturabileceği ve okullar arası eğitimsel kaynak farklılıkların giderilmesinin eğitimde firsat eşitliği bağlamında değerlendirilmesi gerekliliği üzerinde durulabilir. Ülkelerin başarılı eğitim sistemine sahip olabilmesi ve toplumun sadece bir kısmının değil tamamının nitelikli bir eğitime ulaşabilmesi, ancak, başarılı okullara sahip olunması ile mümkün olabilmektedir (Turan, Açıkalın ve Şişman, 2007).

Bir diğer önemli değişken okulda öğrencilere sunulan ekstra etkinlikler değişkenidir. Çocuğun gelişiminde, ders dışı etkinlikler, ders içi faaliyetler kadar önemlidir. Bu tür etkinlikler, öğrencilerin formel öğretim süreci içerisinde öğrendiklerini pekiştiren, bu öğrenmelerin yaşamla ilişkili olduğunu gösteren ve kuramsal öğrenmelerin uygulamaya konulmasını sağlayan etkinliklerdir (Köse, 2013). Ayrıca bu etkinlikler öğrencilerin okula daha yüksek düzeyde bağl111k göstermelerine neden olabilmektedir. Eurydice (2013: 12) hazırladığı raporda okulda yapılan fiziksel etkinliklerin aynı zamanda okul içi şiddet ve zorbalığı azaltmada yardımcı olduğunu, bu nedenle de bazı ülkelerin günlük okul akışına daha fazla fiziksel etkinlik eklemeyi, gün boyunca, teneffüs aralarında ve hatta okul yolunda da bu etkinlikleri gerçekleştirmeye çalıştıklarını ortaya koymaktadır.

Okul akademik başarısı üzerinde en belirleyici olan değişkenleri, eğitimsel kaynakların kalitesi ve öğrencilere sunulan ekstra etkinlikler, incelediğimizde aslında bu değişkenlerin dolaylı veya doğrudan öğrenciyle ilişkili okul iklimi değişkenini etkilediği anlaşılabilmektedir. Diğer bir anlatımla, okulda öğrencilere sunulan ekstra etkinlikler öğrencilerin okula keyfi devamsızlıkları, geç kalmaları gibi istenmeyen bir kültürün oluşmasını engelleyebilmektedir. Bu durumdan hareketle okul akademik başarısını etkileyen değişkenlerin birbiri ile ilişkili bir örüntü içinde olduğu söylenebilir. Dolayısıyla okulun akademik başarısının geliştirilmesi konusunda bütüncül bir yaklaşımla tüm değişkenlerin birlikte düşünülerek geliştirilmesinin yollarının aranması gerekliliği ortaya çıkmaktadır. Diğer taraftan öğrenci/öğretmen oranı, sınıf büyüklüğü ve okul büyüklüğü gibi sayısal, nicel göstergeler okul başarısını etkileyen değişkenler arasında yer 
almasına rağmen göreli önem sırasına göre karşılaştırıldıklarında diğer değişkenler kadar belirleyici olmadıkları anlaşılmaktadır.

\section{KAYNAKÇA}

Açıkalın, A. (2014). Eğitimde insan kaynağının yönetimi. (Edt. Selahattin Turan, Eğitim Yönetimi Teori, Araştırma ve Uygulama). Ankara: Pegem Akademi Yayıncılık.

Akyüz, G. ve Pala, N. M. (2010). PISA 2003 sonuçlarına göre öğrenci ve sınıf özelliklerinin matematik okuryazarlığına ve problem çözme becerilerine etkisi. İlköğretim Online, 9(2), 668-678.

Alacac1, C. ve Erbaş, A. K. (2010). Unpacking the inequality among Turkish schools: Findings from PISA 2006. International Journal of Educational Development, 30, 182-192.

Albayrak, A. (2009). PISA 2006 sınavı sonuçlarına göre Türkiye'deki öğrencilerin fen başarılarını etkileyen bazı faktörler. (Yayımlanmamış Yüksek lisans tezi). Hacettepe Üniversitesi, Ankara.

Alpar, R. (2003). Uygulamalı çok değişkenli istatistiksel yöntemlere giriş. (2. Baskı). Ankara: Nobel Yayınları.

Altınkurt, Y. (2008). Öğrenci devamsızlıklarının nedenleri ve devamsızlığın akademik başarıya olan etkisi. Dumlupınar Üniversitesi Sosyal Bilimler Dergisi, 20, 129-142.

Anıl, D. (2008). The analysis of factors affecting the mathematical success of Turkish students in the PISA 2006 evaluation program with structural equation modeling. AmericanEurasian Journal of Scientific Research, 3(2), 222-227.

Anıl, D. (2009). Uluslararası öğrenci başarılarını değerlendirme programı (PISA)'nda Türkiye'deki öğrencilerin fen bilimleri başarılarını etkileyen faktörler. Eğitim ve Bilim, 34(152), 87-100.

Berberoğlu, G. ve Kalender, İ. (2005). Öğrenci başarısının yıllara, okul türlerine, bölgelere göre incelenmesi: ÖSS ve PISA Analizi. Eğitim Bilimleri ve Uygulama, 4(7), 21-35.

Borman, G., ve Dowling, N. (2012). Schools and Inequality: A multilevel analysis of Coleman's Equality of Educational Opportunity Data. Teachers College Record; (112), 1201-1246.

Boztunç, N. (2010). Uluslararası ögrenci değerlendirme programı (PISA)'na katılan Türk ögrencilerin 2003 ve 2006 ylllarındaki matematik ve fen bilimleri başarılarının incelenmesi. (Yayımlanmamış Yüksek lisans tezi). Hacettepe Üniversitesi, Ankara.

Büyüköztürk, Ş. (2006). Sosyal bilimler için veri analizi el kitabı- istatistik, araştırma deseni, SPSS uygulamaları ve yorum. (6. Baskı). Ankara: PegemA Yayıncılık.

Çif̧ci, A. (2006). PISA 2003 sinavi matematik alt testi sonuçlarına göre Türkiye'deki ögrencilerin başarılarını etkileyen bazı faktörlerin incelenmesi. (Yayımlanmamış Yüksek lisans tezi). Hacettepe Üniversitesi, Ankara. 


\section{Metin ÖZKAN}

Erbaş, K. C. (2005). Uluslararası öğrenci başarı belirleme programında (PISA) Türkiye'de fen okuryazarlı̆̆ını etkileyen faktörler. (Yayımlanmamış Yüksek lisans tezi). Orta Doğu Teknik Üniversitesi, Ankara.

Eurydice, 2013. Avrupa' daki Okullarda Beden Eğitimi ve Spor. Eurydice Raporu. Lüksemburg: AB Yayın Ofisi.

Gürsakal, S. (2012). PISA 2009 Öğrenci başarı düzeylerini etkileyen faktörlerin değerlendirilmesi. Süleyman Demirel Üniversitesi İktisadi ve İdari Bilimler Fakültesi Dergisi, 17(1), 441-452.

Güzel, İ. Ç. (2006). A cross-cultural comparison of the impact of human and physical resource allocations on student's mathematical literacy skills in the programme for international student assessment (PISA). (Yayımlanmamış Doktora tezi). Orta Doğu Teknik Üniversitesi, Ankara.

Koğar, H. (2015). PISA 2012 Matematik okuryazarlı̆̆ını etkileyen faktörlerin aracılık modeli ile incelenmesi. Eğitim ve Bilim, 40 (179), 45-55. DOI: 10.15390/EB.2015.4445

Kurul Tural, N. (2002). Öğrenci başarısında etkili okul değişkenleri ve eğitimde verimlilik. Ankara Üniversitesi Ĕ̈itim Bilimleri Fakültesi Dergisi, 35 (1-2): 39-54.

Lezotte, L. W. (2010). What effective schools do: Re-envisioning the correlates. Indianapolis: Solution Tree

MEB (2015). PISA 2012 Araştırması Ulusal Nihai Rapor. Ankara: İşkur Matbaacılık Ltd. Şti.

OECD (2013a). PISA 2012 Results: What Makes Schools Successful? Resources, Policies and Practices (Volume IV), PISA, OECD Publishing. http://dx.doi.org/10.1787/9789264201156-en

OECD (2013b). PISA 2012 Assessment and Analytical Framework: Mathematics, Reading, Science, Problem Solving and Financial Literacy, OECD Publishing.http://dx.doi.org/10.1787/9789264190511-en

Özdamar, K. (1999). Paket programlar ile istatistiksel veri analizi (çok değişkenli analizler). (2. Bask1). Eskişehir: Kaan Kitabevi.

Özdemir, A. (2002). Sağlıklı okul ikliminin çeşitli görünümleri ve öğrenci başarısı. Kastamonu Ĕgitim Dergisi, 10 (1), 39-46.

Özer, Y. (2009). Uluslararası öğrenci değerlendirme programı (PISA) verilerine göre Türk ögrencilerin Matematik ve Fen Bilimleri başarıları ile ilişkili faktörler (Yüksek lisans tezi, Hacettepe Üniversitesi, Ankara).

Özer, Y. ve Anıl, D. (2011). Öğrencilerin fen ve matematik başarılarını etkileyen faktörlerin yapısal eşitlik modeli ile incelenmesi. Hacettepe Üniversitesi Eğitim Fakültesi Dergisi, 41,313-324.

Şaşmazel, G. A. (2006). Uluslararası öğrenci başarı belirleme programında (PISA) Türk ögrencilerin fen bilgisi başarılarını etkileyen faktörler. (Yayımlanmamış Yüksek lisans tezi). Hacettepe Üniversitesi, Ankara. 
Turan, S., Açıkalın. A. ve Şişman. M. (2007). Bir insan olarak müdür. Ankara: PegemA Yayınc1lik.

Usta, H. G. (2009). PISA 2006 sınav sonuçlarına göre Türkiye'deki ögrencilerin fen okuryazarlı̆̆ını etkileyen faktörler. (Yayımlanmamış Yüksek lisans tezi). Ankara Üniversitesi, Ankara.

Yalçın, S. ve Tavşancıl, E. (2014). Türk öğrencilerin PISA başarı düzeylerinin veri zarflama analizi ile yıllara göre karşılaştırılması. Kuram ve Uygulamada Eğitim Bilimleri, 14 (3), 947-968. DOİ: 10.12738/estp.2014.3.1748

Yıldırım, K. (2009). Uluslararası ögrenci değerlendirme programı (PISA) 2006 yılı verilerine göre Türkiye'de eğitimin kalitesini belirleyen temel faktörler (Doktora tezi, Gazi Üniversitesi, Ankara).

Ziya, E, Doğan, N. ve Kelecioğlu, H. (2010). What is the predict level of which computer using skills measured in PISA for achievement in mathematics. The Turkish Online Journal of Educational Technology [TOJET], 9 (4), 185-191. 